\title{
TITLE:
}

\section{PEDAL LACERATION OF THE SEA ANEMONE, HALIPLANELLA LUCIAE}

$\operatorname{AUTHOR}(\mathrm{S}):$

Atoda, Kenji

\section{CITATION:}

Atoda, Kenji. PEDAL LACERATION OF THE SEA ANEMONE,

HALIPLANELLA LUCIAE. PUBLICATIONS OF THE SETO MARINE

BIOLOGICAL LABORATORY 1973, 20: 299-313

ISSUE DATE:

1973-12-19

URL:

http://hdl.handle.net/2433/175771

RIGHT: 


\title{
PEDAL LACERATION OF THE SEA ANEMONE, HALIPLANELLA LUCIAE
}

\author{
KENJI ATODA \\ Department of Biological Science, Tohoku University \\ Kawauchi, Sendai 980, Japan
}

With Plates I-III and 11 Text-figures

Usually the sea anemone belonging to the normal type (UCHIDA, 1936) of Haliplanella luciae reproduces asexually by pedal laceration (ATODA, 1954a). There are wide variations in the form of laceration pieces and in the number of orange stripes on the column of individuals regenerated from the pieces (Atoda, 1954a). The correlation between the forms of pieces and those of regenerates has been elucidated experimentally (ATODA, 1954c, 1955, 1960).

The process of laceration, however, has not yet been fully understood, and may be manifested in the following observations.

\section{Material and Method}

Most of the anemones collected from Shobuta, Miyagi Prefecture, were of smaller size, having pedal discs measuring about $10 \mathrm{~mm}$ in diameter. Each anemone was separately kept in a round glass vessel measuring about $90 \mathrm{~mm}$ in diameter and about $60 \mathrm{~mm}$ in height, and containing sea water of about $240 \mathrm{ml}$. They were fed with pieces of the adductor muscle of marine bivalves for a long period, and the regenerates resulting from the pieces were fed with brine shrimp larvae.

The process of laceration was sketched in detail, and in addition photographed from the oral side of anemones or from the face of the pedal disc through the vessel wall. The number of siphonoglyphs and the mesenteric arrangement were examined on the preparations of small individuals made by fixing with ZENKER's fluid, imbedding in paraffine, cutting into serial sections, and staining with HeIDENHAIN's iron hematoxylin and orange $\mathrm{G}$.

\section{Observations}

\section{Frequency of Pedal Laceration}

Seventy-four individuals were observed for about 5 months, August to December (1970), and 59 of them acted laceration 1-7 times, 176 times in total. The observation was continued further on 50 individuals which, but 13, had ever undergone laceration, 


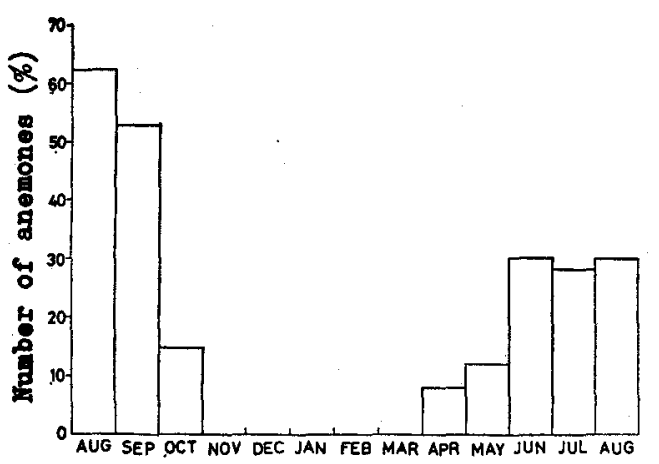

Fig. 1. Number of individuals executed laceration in each month from August, 1970 to the next August.

and 24 experienced and 5 inexperienced individuals acted laceration 1-15 times and 98 times in total during the following 8 months. Throughout the whole abservations at least 64 individuals $(80.5 \%)$ experienced laceration in about 13 months, while a single individual executed fission.

As shown in Figs. 1 and 3, laceration occurred most frequently in August, next in September but much less frequently in October. Then a pause continued till the next March. It again took place in April and become more active with time, though with a slight unexpected drop in July, which might be ascribed to renewed sea water which might have brought about some unhealthy conditions to the anemones, as most of them did not stretch their tentacles to take food after the water renewed early in this month.

The number of individuals executed laceration in each day from August to October fluctuated markedly (Fig. 2). The frequency of laceration observed in 42 anemones during about 13 months was also variable, though predominantly 3 times, then twice (Table 1).

Table 1. Frequency of laceration executed in respective individuals ( 42 in all) in 13 months, shown by times of lacelation.

\begin{tabular}{c|rrrrrrrrrrrr}
\hline \hline No. of times & 1 & 2 & 3 & 4 & 5 & 6 & 7 & 8 & 9 & 10 & 11 & 22 \\
\hline $\begin{array}{c}\text { No. of individuals } \\
\%\end{array}$ & 5 & 8 & 9 & 2 & 4 & 4 & 2 & 1 & 2 & 3 & 1 & 1 \\
\hline
\end{tabular}

The time interval between the first and the next lacerations was quite irregular either individually or even in the same individual.

2. Effect of the Sea Water Temperature on Laceration

As shown in Fig. 2, laceration occurred almost every day from August to mid- 


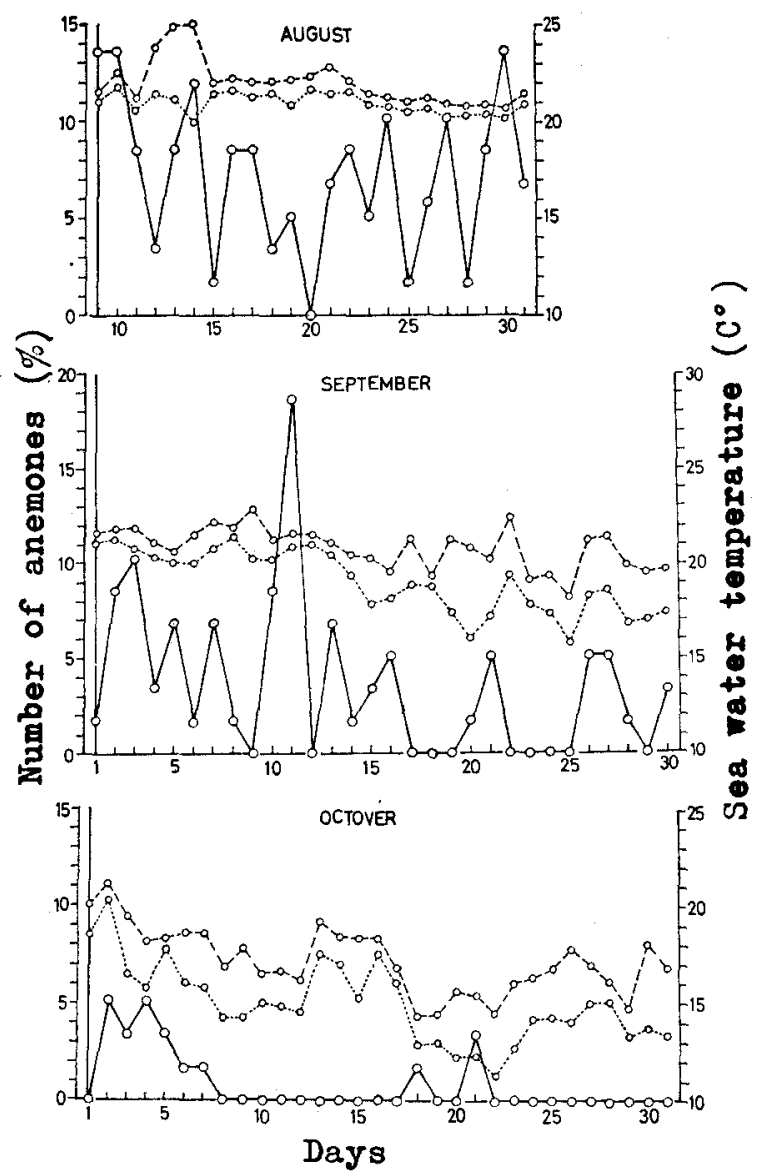

Fig. 2. Number of individuals executed laceration (solid line) and daily maximum (broken lines) and minimum (dotted line) sea water temperatures.

September in the range of about $20-23^{\circ} \mathrm{C}$. It became inactive as the temperature fell from late September to early October and scarcely occurred below $18^{\circ} \mathrm{C}$. Concerning the monthly mean temperature, frequent laceration occurred above $20^{\circ} \mathrm{C}$, but none below $15^{\circ} \mathrm{C}$ (Fig. 3).

In order to confirm the effect of temperature on laceration, additional experiments were made with 6 small anemones, of which 5 had already experienced laceration during the period June to September, by keeping then in a thermostat at $25.5-26.0^{\circ} \mathrm{C}$ in the end of September. All of them executed several times of laceration during a short period. As they separated many pieces in rapid succession without recovering lost portions of the disc, their body finally became strikingly smaller (Table 2). Thus it may be assumed that the optimum temperature for active laceration is above $25.5^{\circ} \mathrm{C}$. 


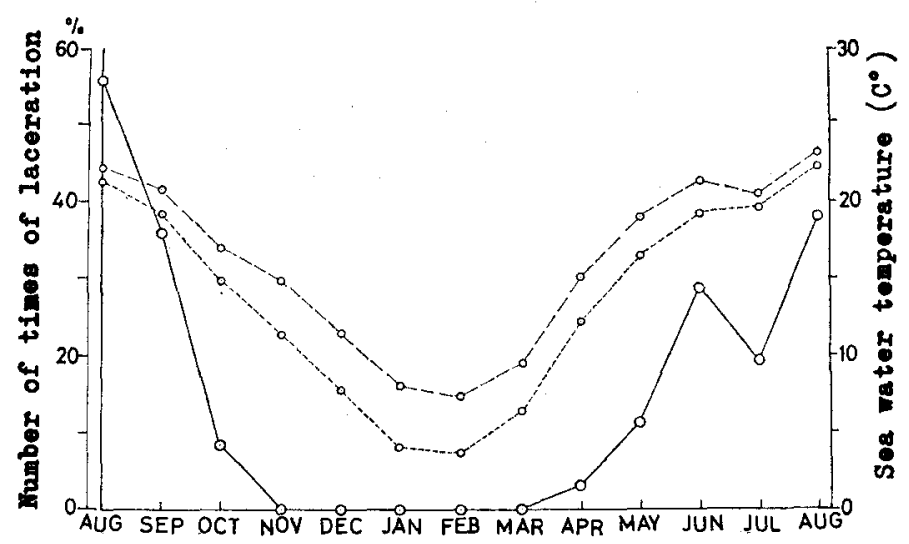

Fig. 3. Frequency of laceration (solid line) and monthly mean maximum (broken line) and minimum (dotted line) temperatures.

Table 2. Frequency of laceration in 6 anemones, under natural conditions or constantly at higher temperatures in thermostat.

\begin{tabular}{|c|c|c|c|c|c|c|c|c|c|c|c|c|}
\hline Animal No. & 1 & 2 & 3 & 4 & 5 & 6 & 1 & 2 & 3 & 4 & 5 & 6 \\
\hline $\begin{array}{l}\text { Days after the } \\
\text { 1st laceration }\end{array}$ & 101 & 88 & 74 & 63 & 43 & 0 & \multicolumn{6}{|c|}{ Kept in the thermostat for 21 days. } \\
\hline $\begin{array}{l}\text { Temperature of } \\
\text { sea water }\end{array}$ & \multicolumn{6}{|c|}{$18.1-25.2^{\circ} \mathrm{C}$} & \multicolumn{6}{|c|}{$25.5-26.0^{\circ} \mathrm{C}$} \\
\hline $\begin{array}{l}\text { No. of times of } \\
\text { laceration }\end{array}$ & 6 & 3 & 2 & 1 & 1 & 0 & 4 & 5 & 2 & 5 & 3 & 5 \\
\hline No. of pieces & 7 & 3 & 3 & 2 & 1 & 0 & 6 & 11 & 4 & 6 & 4 & 6 \\
\hline
\end{tabular}

\section{Process of Laceration}

The whole or nearly whole processes could be observed in 88 times of laceration (Figs. 4, 5; Pls. I-III). At the beginning of the process of laceration, the anemone seemed to shift the body toward some direction. As the anemone stuck fast to the vessel with the pedal disc, especially along its border, a certain part of the disc was strongly strained in the mentioned direction. Thus, a strong tension was loaded on the tissues of that part which became flattened and conspicuously thin, often projected out from the general contour of the disc and with a paler hue, especially with an elongated and fainter orange stripe when it was present there.

Soon the tissues begun to rupture resulting in a small rent at some little distance from the free border of the disc. Then the rent gradually became larger often extending to cover even 2 or 3 stripes. Sometimes several rents appeared near the adjoining stripes or between two stripes were soon united to form a large rent (Fig. 4).

A narrow peripheral portion of the disc bordering the outer side of the rent, thus 


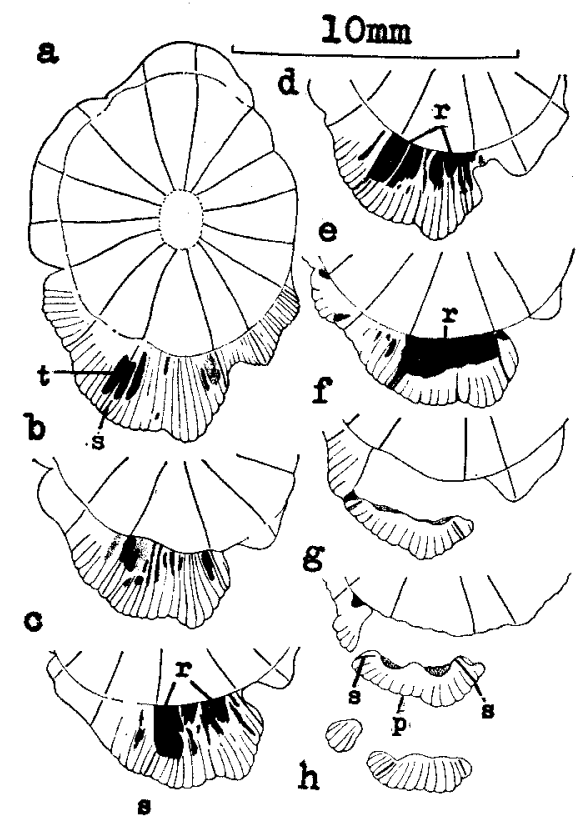

Fig. 4. a, Small part (t) including a stripe (s) of the disc became thin. $b$, The part extended (30 min later). c, Rents (r) appeared (1 hr later). d, Rents widened ( $1 \mathrm{hr}$ $13 \mathrm{~min}$ later). e, Several rents united to form a large one (1 hr $33 \mathrm{~min}$ later). $\mathrm{f}$, Long piece being separated ( $2 \mathrm{hr} 15 \mathrm{~min}$ ). $\mathrm{g}$, Piece (p) with 2 stripes completely separated ( 5 hr $15 \mathrm{~min}$ ). h, Another small plain piece separated from an edge of the remaining border of the disc.

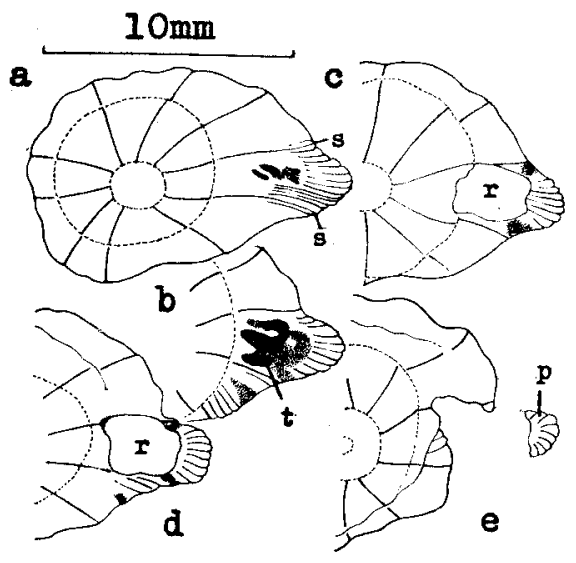

Fig. 5. a, Small part between stripes (s) became thin. $b$, The part $(t)$ widened $(30$ min later). c, Rent (r) appeared (1 hr 20 min later). d, Rent extended along stripes (3 hr 15 min later). e, Plain piece (p) separated (16 hr 45 min later).

formed, finally tore at its either end, rarely at both ends, or on some occasions at about the middle ( $\mathrm{Pl}$. I). After a fairly long time, another end of this portion also tore, and a piece was compeletely separated from the disc.

Sometimes another piece without any stripes on it was separated from an edge of the remaining portion of the disc after the completion of laceration (Fig. 4). Such a plain piece was produced, too, when the part between two adjoining stripes was lacerated or torn at just the stripes (Fig. 5). In addition, some long pieces with a single stripe were divided in halves (Pls. I, III) or divided at just a stripe, resulting in the production of one or two plain pieces. Thus, the stripeless pieces were found in a considerable number (Table 4).

As the diglyphic individuals originate from the pieces with the directives, while the monoglyphic ones from those without them (ATODA, 1960), it was ascertained how frequently laceration took place at the directives in 57 lacerations, 12 lacerations were accomplished at the directives, while the others seemed to be done apart from 
them.

On some occasions the second laceration began before the first had finished, or the third followed the second in close succession (PI. III) and in the result several pieces were produced almost simultaneously. In the former, two lacerations often occurred in the opposite portions of the disc (P1. II, Figs. 12-14), whereas in the latter, three lacerations occurred in contiguous portions (Pl. III, Figs. 4-11).

The early steps of laceration from starting to tearing of the border of the disc seemed to proceed steadily under a strong tension described above in about 1 to $3 \mathrm{hr}$. On the contrary the later steps to the complete separation of a piece advanced rather slowly, in several hours to a few days, occasionally even to several days. The time required to complete the whole process was, however, fairly reduced in the anemones kept at higher temperatures in the thermostat.

\section{Laceration Piece}

Four hundred and two pieces were produced by 274 lacerations, and in most cases a single piece resulted from one laceration (Table 3 ).

The majority of pieces had one stripe corresponding respectively to such pieces as S.D, A.D, S.I, A.I, S.II or A.II (ATODA, 1960), although the plain pieces were not a few as stated above (Table 4).

Table 3. Number of pieces produced by respective lacerations.

\begin{tabular}{l|rrrrrrr}
\hline No. of pieces & 1 & 2 & 3 & 4 & 5 & 6 & 7 \\
\hline $\begin{array}{l}\text { No. of times of } \\
\text { laceration }\end{array}$ & 198 & 43 & 22 & 6 & 3 & 1 & 1 \\
\hline \multicolumn{1}{c}{$\%$} & 72.3 & 15.8 & 8.0 & 2.2 & 1.1 & 0.4 & 0.4 \\
\hline
\end{tabular}

Table 4. Number of stripes in respective pieces.

\begin{tabular}{l|rrrrc}
\hline No. of stripes & 0 & 1 & 2 & 3 & 4 \\
\hline $\begin{array}{c}\text { No. of pieces } \\
\%\end{array}$ & 120 & 215 & 52 & 11 & 4 \\
$\%$ & 29.9 & 53.3 & 12.9 & 2.7 & 1.0 \\
\hline
\end{tabular}

\section{Regeneration}

As shown in Table 5, the regenerates reared over a month included mono-, diand tri-glyphic individuals. However, the majority were diglyphic and the triglyphic individuals were unexpectedly not rare.

The types based on the mesenteric arrangement (ATODA, 1960) were checked on 100 regenerates with well developed mesenteries in about 5-7 months after regeneration. Ten types in 42 monoglyphic regenerates and 8 types in 51 diglyphic ones were observed, of these types XIX and N markedly predominated respectively (Figs. 6, 7). Most 
Table 5. Number of siphonoglyphs in anemones produced by laceration or collected from the field.

\begin{tabular}{c|r|r}
\multirow{2}{*}{ No. of siphonoglyphs } & \multicolumn{2}{|c|}{ No. of anemones } \\
\cline { 2 - 3 } & By laceration & From field \\
\hline 1 & $86(34.0 \%)$ & $97(33.1 \%)$ \\
2 & $139(54.9 \%)$ & $177(60.4 \%)$ \\
3 & $28(11.1 \%)$ & $18(6.1 \%)$ \\
4 & 0 & $10.3 \%)$ \\
\hline Total & 253 & 293 \\
\hline
\end{tabular}

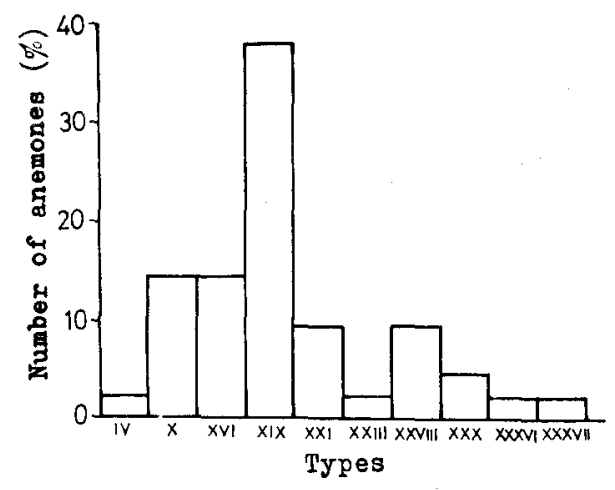

Fig. 6. Types of the monoglyphic regenerates.

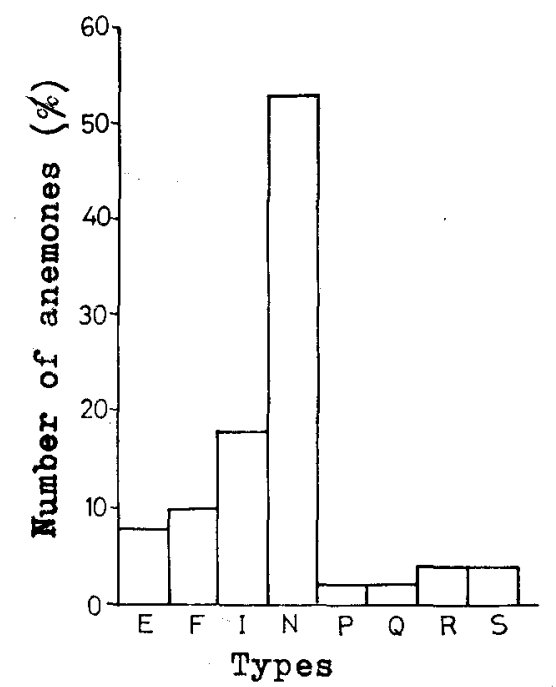

Fig. 7. Types of the diglyphic regenerates.

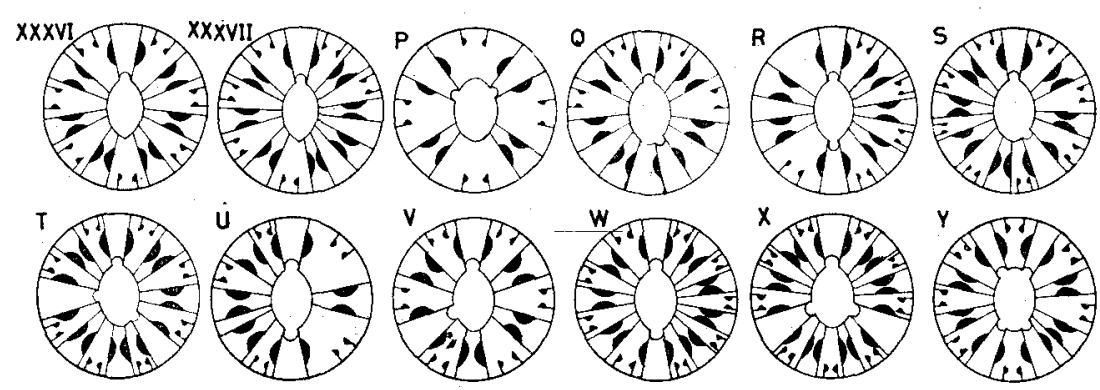

Fig. 8. Mesenteric arrangements of new types found in regenerates (XXXVI-T) and anemones collected from the field (U-Y). 


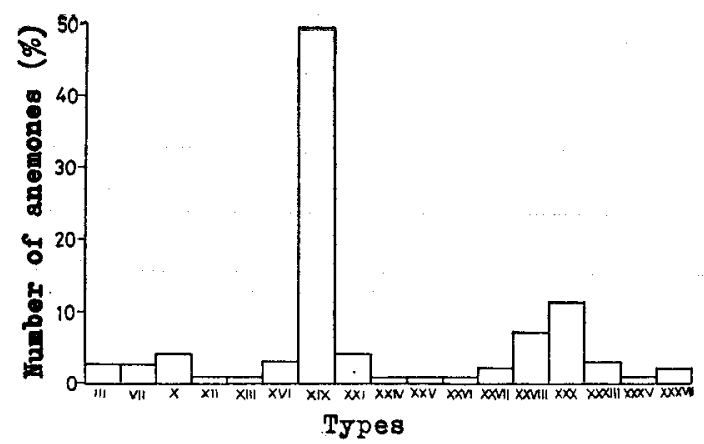

Fig. 9. Types of monoglyphic anemones from the field.

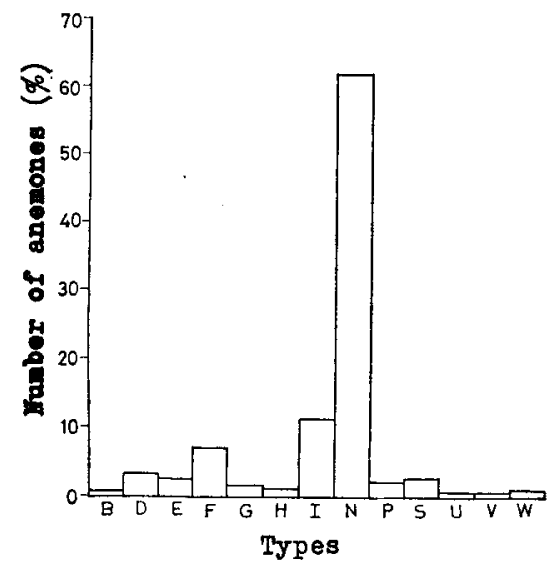

Fig. 10. Types of diglyphic anemones from the field.

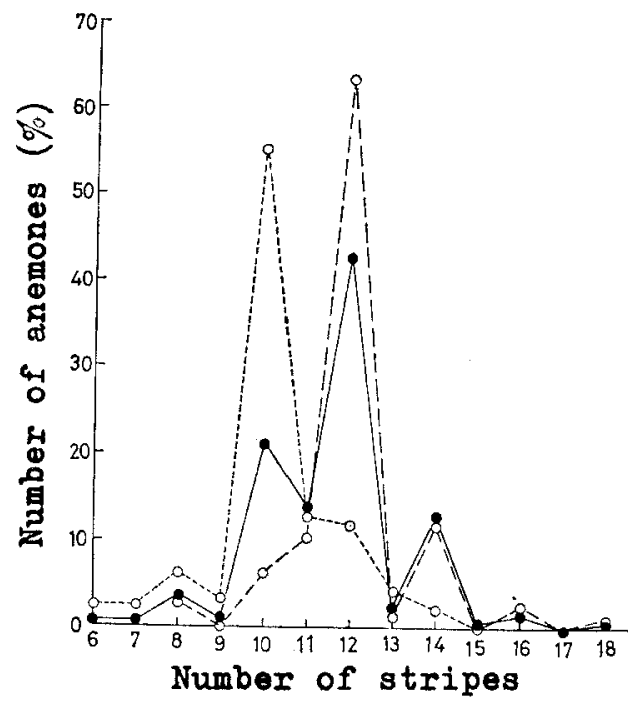

Fig. 11. Number of stripes of monoglyphic (dotted line), diglyphic (broken line), and all anemones (solid line). 
(about $90 \%$ ) of regenerated individuals belonged to the same types as those of individuals produced by artificial laceration (ATODA, 1960), though a few belonged to such new types as XXXVI, XXXVII, P, Q, R and S respectively (Fig. 8). The remaining 7 individuals were triglyphic and belonged to types $\mathrm{M}, \mathrm{L}$ and a new type, $\mathrm{T}$ (Fig. 8).

\section{Anemones Collected from the Field}

The number of siphonoglyphs was checked on small anemones collected from the field, and the results obtained were approximately similar to those obtained on the regenerates (Table 5).

In regard to the mesenteric arrangement, there were 17 types in the monoglyphic individuals and 13 types including 3 new ones, U, V and W (Fig. 8) in the diglyphic. Throughout all types, XIX and $N$ predominated much more than others (Figs. 9, 10). Nearly all triglyphic ones belonged to Type $M$, besides one to each of $L$ and a new type $\mathrm{X}$ (Fig. 8). In addition, a single tetraglyphic anemone of Type $\mathrm{Y}$ was found (Fig. 8). On the whole, $95 \%$ of anemones from the field belonged to the same types as those of individuals produced by artificial or natural laceration.

On the other hand, the number of stripes varied from 6 to 18 with individuals, but, as expected, 12 stripes in the diglyphic and 10 stripes in the monoglyphic predoninated much more, because stripes of these numbers were correlated with types $N$ and XIX respectively. Then 11-stripe individuals were found to some extent, followed by 14 -striped ones (Fig. 11). It has been already reported by UCHIDA (1936) on the anemones collected from various localities that 12--striped specimens always outnumber others.

\section{Consideration}

Concerning the asexual reproduction of the present anemone and closely related species both fission (Torrey and Mery, 1904; HARGITt, 1914; Davis, 1919; UCHIDA, 1936; MryawaKi, 1952) and pedal laceration (Atoda, 1954a; Dufaure, 1961) have been reported. Frequent occurrences of laceration were found in the present observations, but fission also occurred in a single individual and other 10 anemones collected later from the same inhabitation (unpublished observation). It may be an interesting subject for future studies to clear the correlation between these two asexual methods.

Although the temperature of sea water proved to be an essential factor for laceration as in the case of fission in this species (MIYAWAKI, 1952), it still remains unexplained what physiological changes give rise to provoke laceration in anemones as the temperature rises. CARY (1911) who studied the process of laceration in Aiptasia stated that a certain part of the base was strongly stretched and attenuated, then ruptured with the continuation of the contraction of body. In the present species laceration was accomplished in a similar manner, though it may be necessary to 
study the contracting mechanism more precisely.

A good many regenerates were diglyphic, they must originate from pieces with the directive systems (ATODA, 1960), produced only one or two from a single individual. On the contrary, much more pieces without the directives should be produced unless the parts including the directive chambers are selectively lacerated, although laceration often occurred apart from the directive chambers.

It may be possible that triglyphic individuals originate from pieces with stumps of two pairs of the directives as found in fission observed by DAvIs (1919). Such pieces should have several stripes, e.g. 7 in the individual belonging to Type $\mathrm{N}$, but actually any of such long pieces has never been found. Therefore, triglyphic individuals might have originated from other forms of piece. These questions will be solved in furture studies.

The majority of anemones collected from the field were also diglyphic. If they were produced by fission, the above-mentioned results may be natural, because one mono- and one di-glyphic regenerates result from a single monoglyphic parent and two diglyphic ones from a single diglyphic parent (DAvis, 1919). Their types, however, were almost similar to those of regenerates arisen from laceration pieces, and further the predominant types were also common to natural individuals and regenerates. Moreover, there was a considerable difference in number of stripes between the present specimens from the field and those produced by fission (DAvis, 1919), thus it may be assumed that they reproduce by laceration not only in the laboratory but also in the field.

\section{Summary}

1. Pedal laceration occurred frequently at sea water temperature above $20^{\circ} \mathrm{C}$, but became inactive as the temperature decreased. It scarcely occurred at monthly mean temperatures below $15^{\circ} \mathrm{C}$.

2. Frequency of laceration varied markedly with individuals, but 3 times of laceration predominated in about 13 months and followed by twice.

3. At the beginning of laceration some small portion at a little distance from the disc border became extremely thin, then ruptured to become a rent. The border on the outer side of the rent was separated from the disc as a piece. Usually a piece with a single stripe was produced by one laceration.

4. It took a considerably long time to finish the whole process of laceration, though the early steps proceeded steadily rather in a short time. Sometimes 2 or 3 lacerations occurred in close succession in the same individual.

5. A good many regenerates were diglyphic, and the triglyphic ones were not a few. Nearly all regenerates belonged to the same types as those of regenerates produced by artificial laceration, the types $\mathrm{N}$ and XIX being exceedingly predominant.

6. The number of siphonoglyphs and the mesenteric arrangements of the a- 
nemones collected from the field were very similar to those of the regenerates arisen from laceration pieces, and 12-striped anemones markedly predominated, being followed by $10-$ striped ones.

\section{REFERENCES}

AtodA, K., 1954a. The development of the sea anemone, Diadumene luciae, reproduced by the pedal laceration. Sci. Rep. Tohoku Univ., 4th Ser. (Biol.), 20: 123-129.

,$- 1954 \mathrm{~b}$. The development of the sea anemone, Diadumene luciae II. The individuals originated from the fragments without stripes by artificial laceration. Ibid., 20: 362-269.

-1955 . The development of the sea anemone, Diadumene luciae III. The individuals which originate from the fragments with one stripe by pedal laceration. Ibid., 21: 89-95.

-1960 . The development of the sea anemone, Diadumene luciae IV. The correlation between the forms of laceration pieces and those of the regenerates. Bull. Mar. Biol. Stat. Asamushi, 10: $87-94$.

Carry, L. R., 1911. A study of pedal laceration in Actinians. Biol. Bull., 20: 81-108.

DAvis, D. W., 1919. Asexual multiplication and regeneration in Sagartia luciae VerRILl. J. Exp. Zool., 28: 161-263.

Dufaure, J. -P., 1961. Sur des potentialités histogénétiques chez 1'Actinie Diadumene cincta StePHENSON. Bull. Soc. Zool. France, 85: 389-395.

Hargitt, C. W., 1914. Anthozoa of the Woods Hole region. Bull. Bur. Fisheries, 32: 223-254.

MrYAWAKI, M., 1952. Temperatures as a factor influencing upon the fission of the orange-striped sea-anemone, Diadumene luciae. J. Fac. Sci. Hokkaido Univ. Ser. 6, Zool., 11: 77-80.

Torrey, H. B., and J. R. Merry, 1904. Regeneration and non-sexual reproduction in Sagartia davisi. Univ. Cal. Pub. Zool., 1: 211-226.

UCHIDA, T., 1936. Influence of the currents upon the distribution of races and frequency of asexual reproduction in the actinian, Diadumene luciae. Zool. Mag., 48: 895-906 (Japanese with English résumé).

\section{EXPLANATION OF PLATES I-III}

\section{PLATE I}

Fig. 1. Beginning of laceration.

All photographed from the oral side.

Fig. 2. Rent begun to appear. Some of acontia emitted from various parts of the body obturating the rent ( $30 \mathrm{~min}$ later).

Figs. 3, 4. Rent widened ( $45 \mathrm{~min}, 1 \mathrm{hr} 15 \mathrm{~min}$ later).

Fig. 5. The periphery bordering the outer side of the rent begun to tear ( $1 \mathrm{hr} 30 \mathrm{~min}$ later).

Fig. 6. The border tore ( $2 \mathrm{hr} 40 \mathrm{~min}$ later).

Figs. 7, 8. Rent much more widened (4 hr, $4 \mathrm{hr} 10 \mathrm{~min}$ later).

Fig. 9. Long piece just separated ( $5 \mathrm{hr} 10 \mathrm{~min}$ later).

Figs. 10, 11. The same state continued ( $5 \mathrm{hr} 30 \mathrm{~min}, 22 \mathrm{hr}$ later).

Fig. 12. Initial piece divided in halves, and another additional piece separated from the remaining border ( 3 days later). 


\section{PLATE II}

All photographed from the face of the pedal disc.

Fig. 1. Round rent appeared.

Figs. 2, 3. Rent widened ( $30 \mathrm{~min}, 1 \mathrm{hr}$ later).

Fig. 4. Border of the disc tore ( $2 \mathrm{hr} 35 \mathrm{~min}$ later).

Figs. 5-8. Rent widened gradually ( $3 \mathrm{hr} 30 \mathrm{~min}$ to $4 \mathrm{hr} 50 \mathrm{~min}$ later).

Figs. 9, 10. Piece separated ( 5 hr $2 \mathrm{~min}, 6 \mathrm{hr}$ later).

Fig. 11. Anemone moved for a short distance (21 hr later).

Figs. 12-14. Two lacerations in another anemone. A piece (Fig. 13, about 2 days later), then another one (Fig. 14, about 7 days later) being separated.

\section{PLATE III}

All photographed from the face of the pedal disc.

Fig. 1. Small portion ( $t$ ) of the border of the pedal disc became extremely thin.

Fig. 2. The portion begun to tear (14 min later).

Fig. 3. Rent begun to appear in the portion (20 min later).

Fig. 4. Rent (1st) widened (1 hr 40 min later).

Fig. 5. Another portion near the rent begun to become thin ( $2 \mathrm{hr} 34 \mathrm{~min}$ later).

Fig. 6. Portion on the outer side of the rent just torn ( $2 \mathrm{hr} 54 \mathrm{~min}$ later).

Fig. 7. Thin portion shown in Fig. 5 widened ( $3 \mathrm{hr}$ later).

Fig. 8. Second rent ( $2 \mathrm{nd}$ ) begun to appear ( $3 \mathrm{hr} 30 \mathrm{~min}$ later).

Fig. 9. Piece just separated in a state to be divided in halves ( $5 \mathrm{hr} 14 \mathrm{~min}$ later).

Fig. 10. Portion on the outer side of the second rent about to tear (6 hr 30 min later).

Fig. 11. Third rent ( $3 \mathrm{rd}$ ) begun to appear between the two rents ( $7 \mathrm{hrs} 20$ min later).

Fig. 12. Four pieces produced by 3 lacerations $(20 \mathrm{hr}$ later). 
Proc. Second Internat. Symp. Cnidaria
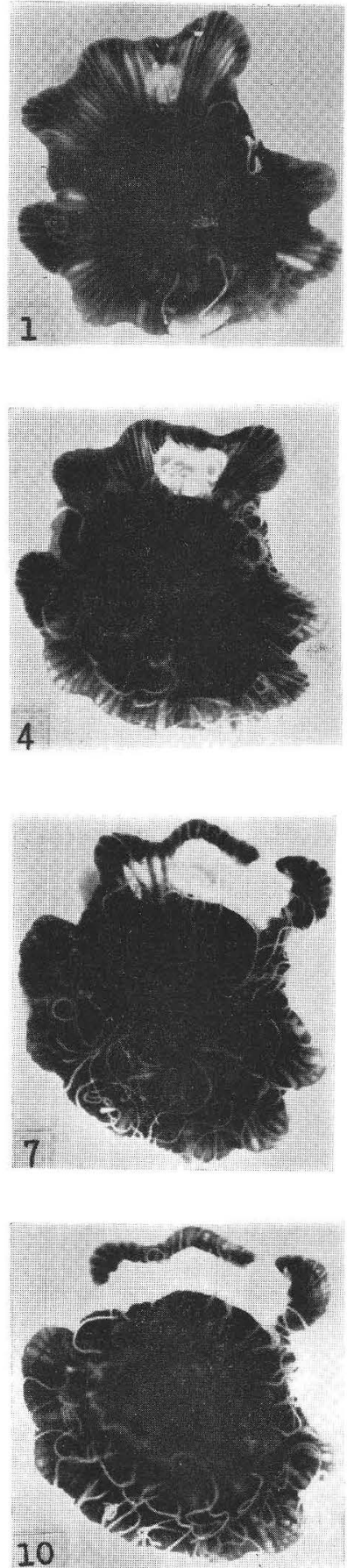
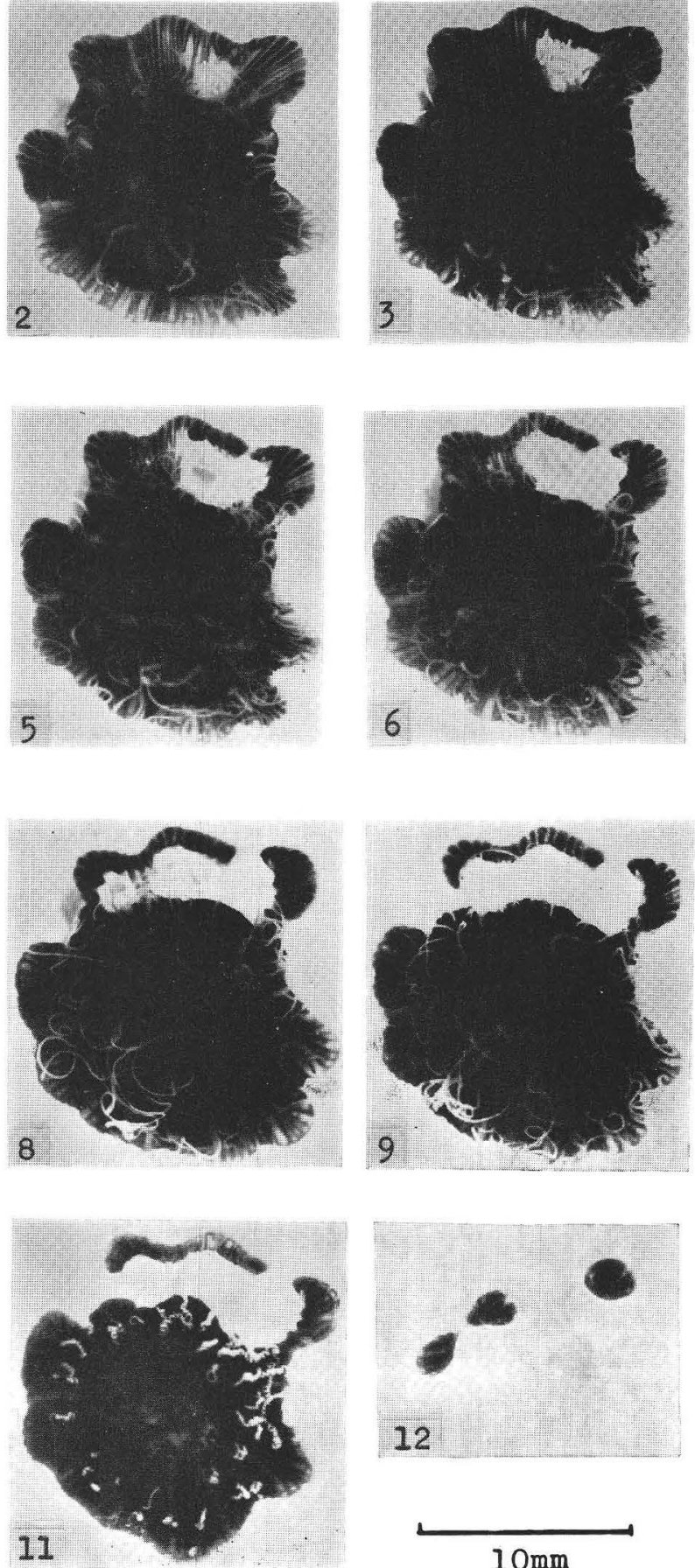

$10 \mathrm{~mm}$

K. Atoda: Pedal Laceration of Sea Anemone 
Proc. Second Internat. Symp. Cnidaria
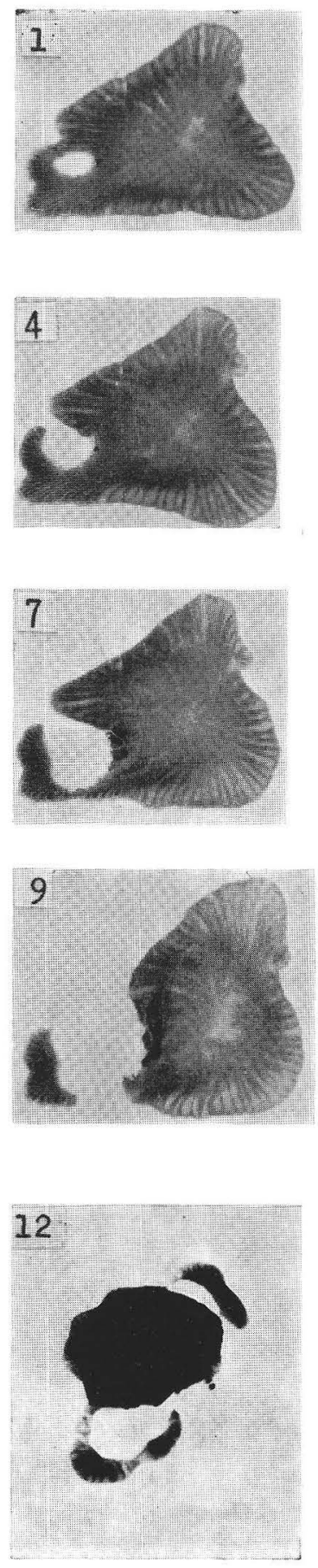

PLATE II
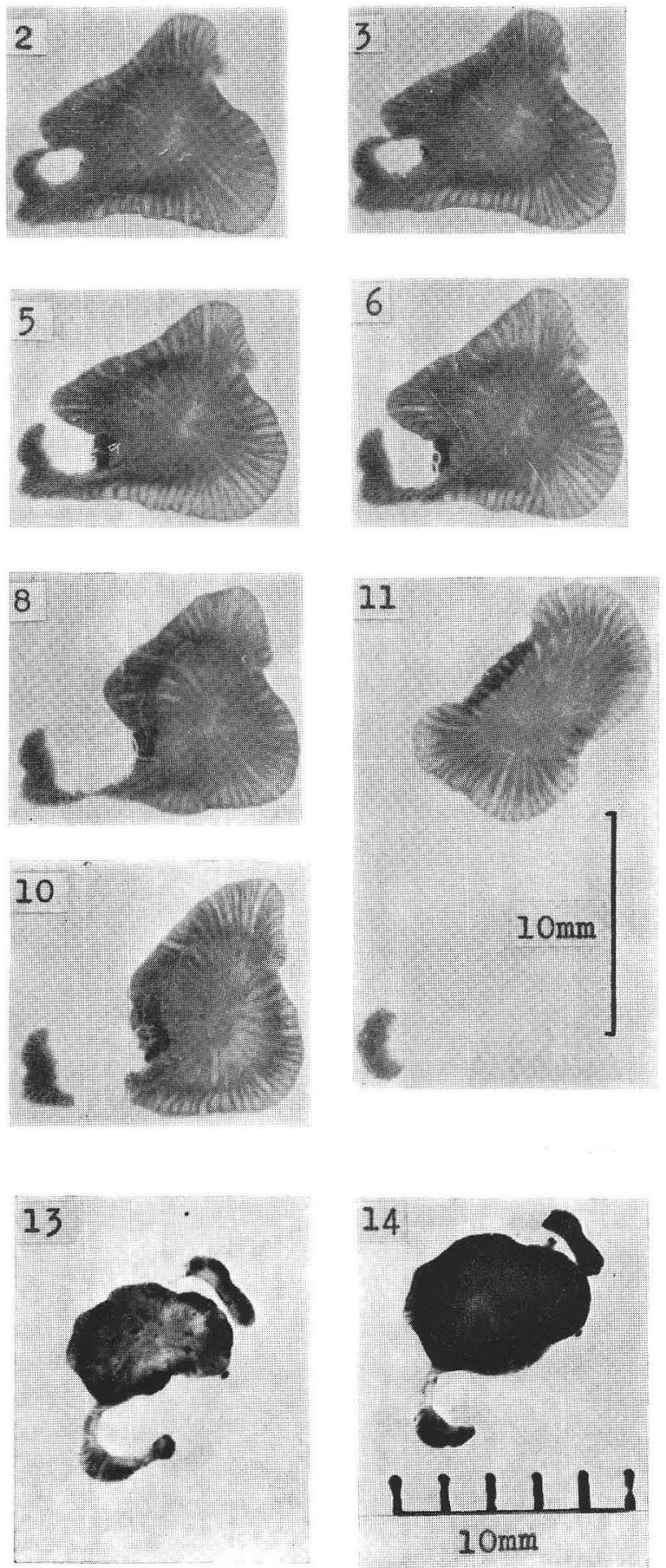

K. Atoda: Pedal Laceration of Sea Anemone 
Proc. Second Internat. Symp. Cnidaria
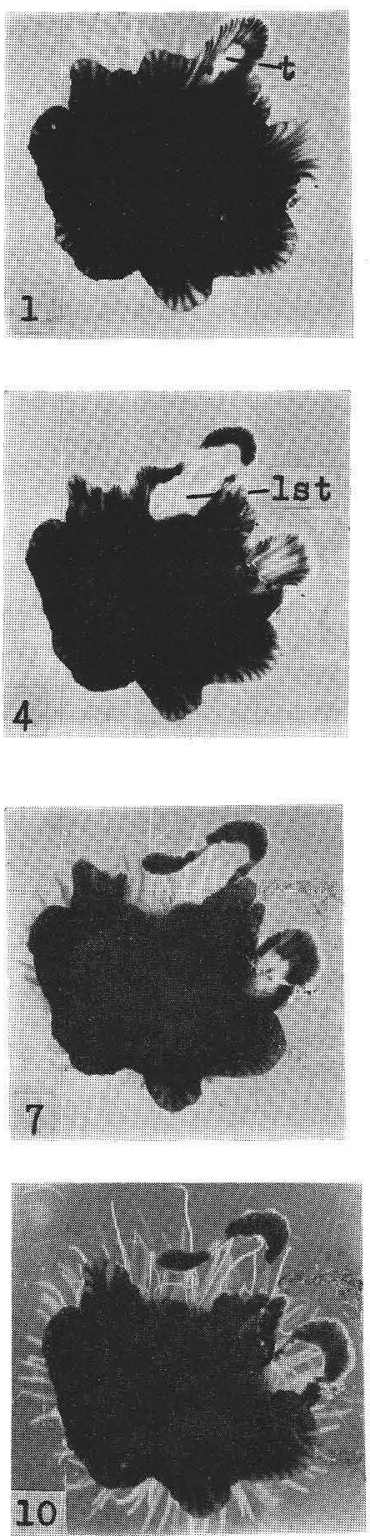
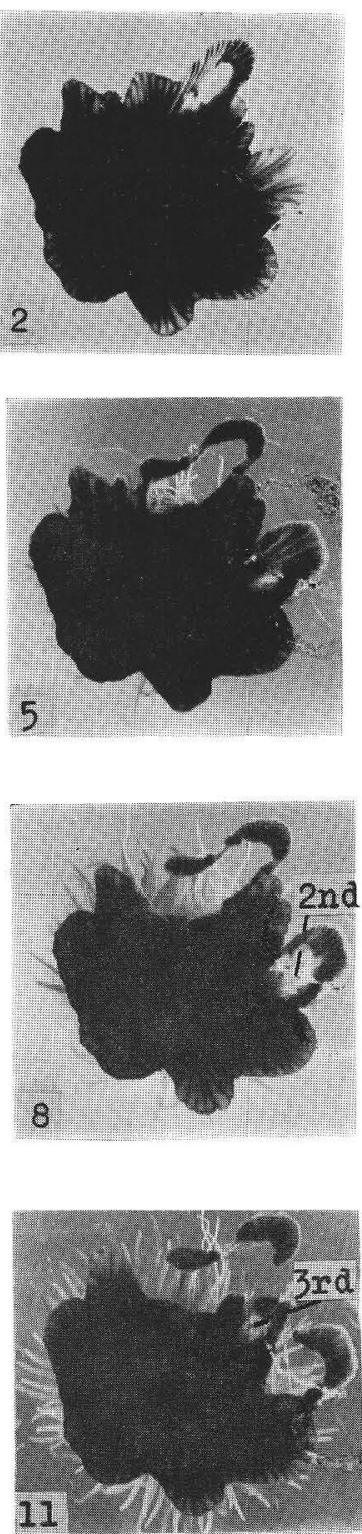

$10 \mathrm{~mm}$
PLATE III
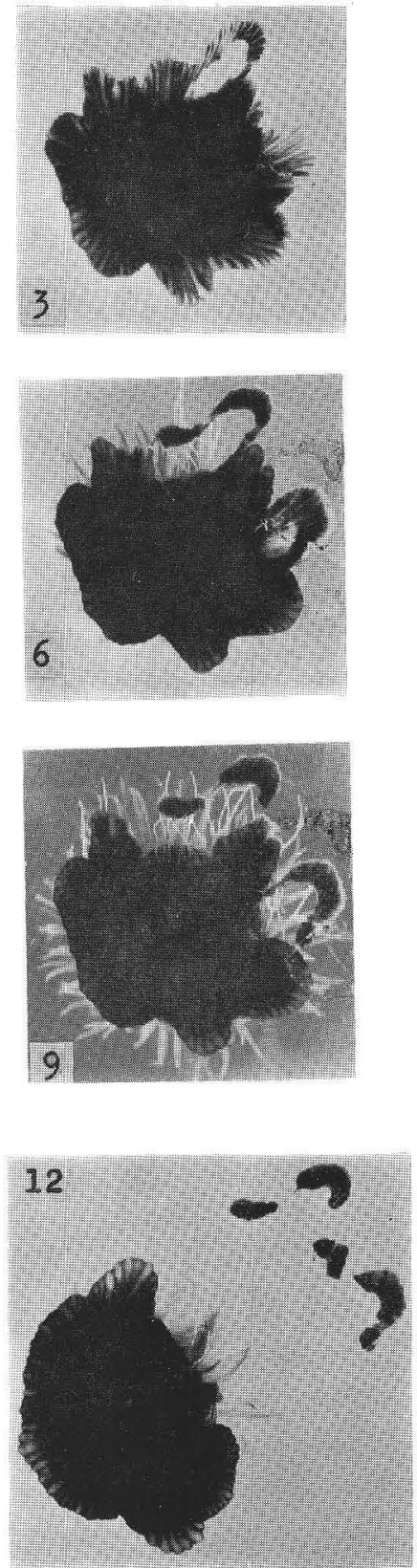

K. Atoda: Pedal Laceration of Sea Anemone 